\title{
信濃における一間社本殿の平面寸法決定方法について THE METHOD OF TAKING DIMENSIONS OF A PLAN OF ONE-SPAN SHINTO SHRINE IN NAGANO PREFECTURE
}

\author{
吉 澤 政已 \\ Masami YOSHIZAWA
}

\begin{abstract}
The present author inquires into the relationship between local builders' methods of taking the dimensions of a plan of one-span Shinto shrine in Sinano(Nagano prefecture) and the method shown in manuals published in the early eighteenth century. Analyses in this paper are based on the number of rafters, the width and length of the main building, and the width of Gohai. As a result, a number of local builders in Sinano knew the method in the manuals, but not more than half of builders adopted them. And therefore, other builders contrived their own methods of taking the dimensions of a plan.
\end{abstract}

Keywords: one-span-shinto shrines,kiwari-syo,si-wari,Edo Period, Nagano prefecture

一間社、木割書、枝割、江戸時代、長野県

\section{1.はしめに}

近世の大工技術書に関する研究は、技術書の内容・成 立年代や系統に至るまで研究成果が発表されているい。 また、近世社寺建築の調查が進むにつれて、各地の技術 水準の高い大工やその系統などが次第に明らかとなって いる2〉。しかし、幕府や藩に属さない数多くの民間の大 工がどのような木割法を用いていたのかという点につい ては、建物以外に文字として残された資料は少ない3”。 彼らがどのような木割法に基づいて建筑を建てたのか、 また、一派とみられる大工に様式的な特徴だけでなく、 木割りについても共通する事柄があるのかどうか、ある いは、刊行されていた技術書の木割りがそのまま導入さ れたのか4などについては、不明の点が多い。

本稿は、江戸時代の信濃国の社寺建築を建てた大工た ちが、どのような技術らを用いていたのかを文献と遗構 調查で得られた資料から考究するものである。具体的に は神社本殿の形式で最も一般的な一間社流造および一間 社隅木入春日造など一間社の建築について、垂木数と柱
間寸法から、彼らの平面寸法の決定方法、時代的な特色 および木割書にみられる柱間决定法の影響などを明かに することを目的とした。

方法は、まず、木割書および長野県内に残されている 建地割図などから柱間寸法の决定方法にどのようなタイ ブがあるのか整理し、次に、その設計によって建てられ た建築の寸法を分析することによって逆に柱間決定法が 特定できるのか検討する。さらに、この検討結果に基づ いて、長野県内の一間社の建築について、こうしたタイ プの柱間决定法と比較検討する ${ }^{6)}$ 。

本論で分析した一間社の建築は、昭和56年度と平成 2 年度に長野県教育委員会が実施した「長野県近世社寺建 築緊急調査」の調査、平成 2 年に発刊された『長野県史』 美術建築資料編 (2)建築7) の調査、および筆者の調査に よって実測値を得られた合計 198棟である。数字的には 長野県内の神社本庁登録法人数 2,456 と比較すると少な い棟数ではあるが、上述の調查は主に県下全域の 1 次調 查の中から技術的に筫の高い建築が選定され夷測されて
信州大学工学部社会開発工学科 大学院生. I修
Graduate Student, Dept. of Architecture and Civil Engineering, Faculty of Engineering, Univ. of Shinshu, M. Eng. 
おり、それぞれの時代の代表的な建築の傾向は示されて いると考える。

建築年代の区分は、建築史で一般に用いられている区 分にしたがった。江戸中期に関しては、前述の技術書が 元禄末年から享保年間には既刊されているのて、元禄期 までの前半と享保期以降の後半に分けて分析した。なお、 検討対象の 198 棟については、江戸前期以前が30棟、江 戸中期前半が38棟、江戸中期後半が42棟、江戸後期が66 棟、江戸末期・近代が22棟である。

\section{2. 近世史料にみられる柱間决定法と测定誤差}

本稿では、木割書など以下の史料を用いる。また、そ こに示された一間社社殿の平面の决定に用いられた数值 を表一 1 にまとめた。

\section{(1) 『匠明』}

『匠明』は江戸幕府作事方大棟梁平内家の水割書て、 慶長13年(1608)の奥書がある。現在伝わる写本は元禄10 年〜享保12年に成立したとされる ${ }^{8)}$ 。本論では、「平作 壱間社之図」(一間社流造を記している。以下本稿で仙 この図の方法をく匠明(1) >と仮称する）と「壱間社之図 (向妻作り)」(一間社隅木入春日造を記している。く匠 明(2)>と仮称する）の柱間決定法を用いた9)。

\section{（2）『新編拾遗大工規矩尺集』}

『新編拾遗大工規矩尺集』（京都・永田調兵衛版）は 元禄13年(1700)に出版された技術書て、、本論では「四尺 五寸之宮」（〈規矩尺集(1) >と仮称する）の項と、「一 しゃ社之事」（<規矩尺集(2)>と仮称する）の項の柱間 决定法を用いた ${ }^{10) 。 ~}$

\section{（3）『大匠蒦形』}

『大匠雅形』(江戸・須原茂兵衛版) は享保 2 年(1717) に再版された技峏書いで、本論では「一間社流作」と 「一間社向作」の柱間決定法を用いた。

\section{（4）伊藤弥兵衛の建地割図}

高島藩御大工伊藤弥右衛門（権兵衛光福）の子孫であ る伊藤富夫氏に伝わる一間社流造の建地割図（<弥兵衛 図>と仮称する）で、「豙保十七㺭年十月日 伊藤弥兵 衛」の署名がある(2)。

（5）掛子造 (3)

挂子造は、『日本建築辞曼』に紹介されている柱間决 定方法で、間口 6 尺末淦の社殷に用いる决定法とされる。 また、高木家文書に記された掛子造を吉田高子氏が分析 されている。

上述の技街書などと実際の建築について検討する前に、 测定誤差の範囲について検討しておきたい。 本諭で分析した実湘值は、主に弛緩の少ない縁長押 （切目長押）・䫒貫位膡等で計測された数値で、複数の
表一 1 技術書等の柱間決定法

\begin{tabular}{|c|c|c|c|c|c|}
\hline & 間口(L) & 行 & 向拝奥行 & 圧直径 & 向拝柱径 \\
\hline 匠明(1) & 22 枝 & 16枝 & 15枝 & - & -1 \\
\hline 匠明(2) & 22枝 & 20枝 & 17枝 & $0.1 \mathrm{~L}$ & $0.08 \mathrm{~L}$ \\
\hline 規矩尺集(1) & 18 枝 & $0.88 \mathrm{~L}$ & $0.76 \mathrm{~L}$ & $0.12 \mathrm{~L}$ & $0.096 \mathrm{~L}$ \\
\hline 規矩尺巢(2) & 20枝 & $(0.9 \mathrm{~L})$ & $(0.8 \mathrm{~L})$ & $0.1 \mathrm{~L}$ & $0.08 \mathrm{~L}$ \\
\hline 大匠雅形 & 22 枝 & 18枝 & 17 枝 & $0.1 \mathrm{~L}$ & $0.08 \mathrm{~L}$ \\
\hline 掛子造 & $\mathrm{L}$ & $0.8 \mathrm{~L}$ & $0.61 \mathrm{~L}$ & $0.1 \mathrm{~L}$ & $0.08 \mathrm{~L}$ \\
\hline 弥兵衛図 & 20枝 & $0.9 \mathrm{~L}$ & $(0.7 \mathrm{~L})$ & $0.1 \mathrm{~L}$ & $0.08 \mathrm{~L}$ \\
\hline
\end{tabular}

表 -2 決定值と実測值の誤差

\begin{tabular}{|c|c|c|c|c|c|c|}
\hline 建物名 & \multicolumn{3}{|c|}{ 武水別神社高良社 } & \multicolumn{3}{|c|}{ 安山落合神社本殿 } \\
\hline 区 分 & 間 口 & 奥 行 & 向 洋 & 間 口 & 奥 行 & 向 拝 \\
\hline 決定值 & 46.00 & 41.20 & 36.00 & 62.00 & 62.00 & 46.50 \\
\hline 譟 差 & 0.20 & 0.50 & 0.37 & 0.33 & 0.33 & 0.30 \\
\hline 翼差比 & 0.004 & 0.013 & 0.01 & 0.005 & 0.005 & 0.006 \\
\hline
\end{tabular}

\begin{tabular}{|c|c|c|c|c|c|c|}
\hline 建物名 & \multicolumn{3}{|c|}{ 大宮熱田神社本殿 } & \multicolumn{3}{|c|}{ 同若宮八幡宮本殿 } \\
\hline 区分 & 間 口 & 奥 行 & 向 拝 & 間 口 & 奥 行 & 问 拝 \\
\hline 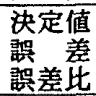 & $\begin{array}{r}60.00 \\
0.20 \\
0.003\end{array}$ & $\begin{array}{r}53.00 \\
0.10 \\
0.002\end{array}$ & $\begin{array}{r}39.70 \\
0.30 \\
0.008\end{array}$ & $\begin{array}{r}40.30 \\
0.10 \\
0.002\end{array}$ & $\begin{array}{r}35.70 \\
0.20 \\
0.006\end{array}$ & $\begin{array}{r}25.60 \\
0.30 \\
0.012\end{array}$ \\
\hline
\end{tabular}

数値が得られているものについてはその平均值を用いて いる。しかし、解体修理されていない建築の場合は、あ る程度の弛緩が認められるので、実测数値はそのまま仕 事真墨とならない場合が多い。そこで、解体修理された 建物について、解体以前の実測值と解体後の決定寸法と を比較して誤差の範囲を决定することにした。

愦差範囲の検討対象とした建築は、武水別神社高良社 社殿 (県宝、更埴市) ${ }^{14}$ )、葛山落合神社本殿(重要文化 財、長野市) 15)、それに大宮熱田神社本殿 ${ }^{16)}$ 之同若宮 八幡宮本殿の 4 棟である(表一 2 )。表－2によれば、誤 差比率 (誤差－决定寸法) は、0.002から0.013の範囲に ある。この結果から、本論ではそれぞれの実測値と仕事 真量との唄差を最大でく実測値 $\times 0.015>$ にあるとみて、 この範囲で数値を分析することとした。

\section{3. 技術書の柱間決定法のタイプと誤差内の分析}

ここでは、まず前述の技術書等にみられる柱間決定法 をタイプ分けする。次に、技術書等に従って建てられた 建築のモデルを想定し、これを実湘した場合、前述の誤 差く実測値 $\times 0.015>$ があっても数值から設計側の柱間 決定法が判断できるか検討した。

技術書等は、柱間を决定する際に間口を基準として、 I : 枝割型一間口に対する奥行、向洋奥行を枝数(整 数值）によって決定するタイプ。

II : 内法心々型一間口の内法を奥行の柱間心に移し、 その奥行の内法を向洋奥行の柱間心に移すタイプ。

III：内法外法型一間口の内法を奥行の柱間伙法に移 し、奥行の内法を向抙奥行の外法に移すタイプ。

IV : 母屋内法型 一 II、IIIタイプに属さないが母屋奥 行を杜径 1 つ分または 2 つ分诚らすタイプ。 IV 、は母屋奥行を柱 1 本分减らすタイプとする。 $\mathrm{IV}_{2}$ は母屋奥行を柱 2 本分堿らすタイプとする。 
の4タイプをとっている。

これらの設計方法を混在させる方法や、間口：奥行： 向拝奥行を単純に $1: 0.9: 0.8$ などのような比率（表一 3 の規矩尺集(2)参照) にする方法も考えられるが、本稿 ではこの 4 つのタイプに基づき分析を進める。

上述のタイプは、垂木の数か柱の直径かに設計方法を 依存している。IIタイプは間口の内法を奥行の心々にと るので、間口寸法と奥行寸法の差は母屋柱 1 本分となる （〈間口寸法一奥行寸法〉 $\div$ 〈柱の直径〉=1）。つまり、 柱の直径に依存するタイプは（間口寸法一奥行寸法）－ 柱の直径、（奥行寸法一向拝奥行寸法）－柱の直径 の 数值（以下＜対母屋柱比>と称する）が整数となり、枝 数に依存するタイプは枝数が整数値となる。

そこで技術書等の方法（表ー1）で决定された柱間や 垂木の数値のみを手掛かりとして、柱間决定方法の夕イ プへの属性を判断できるのか検討した。この場合、技術 書の柱間决定方法の手順をとりながらも、垂木の数や柱 の直径を変更してもタイプ属性が判断できなければ実測 建物との検討は有効とはならないので、いくつかの類例 を加えて検討した。

匠明(1)は枝数 $22 \cdot 16 \cdot 15$ の設計で、間口 $(\mathrm{L}=1)$ に 対する奥行、向据奥行の比率はそれぞれ 16/22 0.73 、 $15 / 22$ ○ 0.68 となる。柱の太さを L $/ 10=0.1$ と仮定する と、間口と奥行の差 $(1-0.73=0.27)$ の柱太さに対する 比率は $0.27 / 0.1=2.7$ 、奥行之向拝奥行の差 $(0.73-0.68$ $=0.15)$ の柱太さに対する比率は $0.15 / 0.1=1.5$ となる。

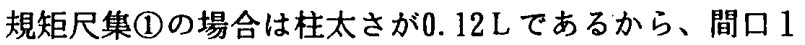
に対して奥行は $1-0.12=0.88$ 亡なり、向拝奥行は 0.88 $-0.12=0.76$ となる。この比率を間口枝数 18 に掛け算す ると奥行枝数は 15.8 、向拝奥行枝数は 13.7 となる。この ような計算結果を表ー 3 にまとめた。

\section{表ー3 技術雷等の柱間比率および枝割}

\begin{tabular}{|c|c|c|c|c|c|c|c|}
\hline 項 & \multicolumn{2}{|r|}{ 枝 割 } & 柱間比率 & \multicolumn{4}{|c|}{ 対母屋柱比 } \\
\hline$\widehat{\nabla}$ & 間口 & 奥行 向拝 & 奥行 向挥 & 奥差 & 向差 & 柱直径 & タイブ \\
\hline 明(1) & 22 & $16 \quad 15$ & 0.730 .68 & 2.7 & 1.5 & 0.1 & I \\
\hline 明(2) & $\overline{22}$ & 20 & 0.910 .77 & 0.9 & 1.4 & 0.1 & I \\
\hline 類例(i) & 22 & 20 & $\begin{array}{lll}0.91 & 0.82\end{array}$ & 1.0 & 1.0 & 0.09 & I or II \\
\hline 類例(2) & $\overline{22}$ & 18 & 0.820 .64 & 2.0 & $\overline{2.0}$ & 0.09 & I or III \\
\hline 規矩尺集(1) & 18 & 15.813 .7 & $0.88 \quad 0.76$ & 1.0 & 1.0 & 0.12 & II \\
\hline 類例(3) & 20 & 17.615 .2 & $0.88 \quad 0.76$ & 1.0 & 1.0 & 0.12 & II \\
\hline 類例(4) & 22 & 19.416 .7 & $\begin{array}{lll}0.88 & 0.76\end{array}$ & 1.0 & 1.0 & 0.12 & II \\
\hline 規矩尺榃(2) & 20 & $18 \quad 16$ & $0.90 \quad 0.80$ & 1.0 & 1.0 & 0.1 & I or II \\
\hline 類例(5) & 22 & 19.817 .6 & 0.80 & 1.0 & 1.0 & 0.1 & II \\
\hline 大匠觹形 & 22 & $18 \quad 17$ & $\begin{array}{lll}0.82 & 0.77\end{array}$ & 1.2 & 0.5 & 0.1 & I \\
\hline 掛子造(1) & 20 & 12.2 & 0.80 & 2.0 & 1.9 & 0.1 & III \\
\hline 掛子造(2) & 22 & $17.6 \quad 13.4$ & 0.80 & 2.0 & 1.9 & 0.1 & WI \\
\hline 掛子造(3) & 20 & 15.210 .6 & 0.760 .53 & 2.0 & 1.9 & 0.12 & III \\
\hline 弥兵衛図 & 20 & $18 \quad 14$ & 0.900 .70 & 1.0 & 2.0 & 0.1 & I or IV \\
\hline
\end{tabular}

注 1：ＩｏrＩは、I または II と判断されることを示す。

注 2 : 枝割一間口は間口枝割、奥行は奥行枝割、向拝は向拝奥 行枝割を示す。

柱間比率 一 奥行は間口（L=1）に対する奥行の比率、 向挥は間口に対する向挥奥行の此率を示す。 奶母屋柱比 一奥行は表間口と奥行の差を母屋柱の直径て 除した数値、向拝は奥行と向拝奥行の差を母屋柱の直径で 除した数值を示す。
類例(1)は、垂木数を22、柱の直径を 2 枝分にとり、奥 行・向拝奥行は 2 枝ずつ減じたもの。類例(2)は、同様に 4 枝ずつ減じたもの。類例(3)、規矩尺集(1)の垂木数を 20としたもの。類例(4)は、規矩尺集(1)の垂木数を22とし たもの。類例(5)は、規矩尺㫦(2)の垂木数を22としたもの である。また、掛子造は、垂木数に依存していないので 20 と22で算出し、柱の直径を間口の0.12にとる場合も想 定した。表中の枝割<間口・奥行・向拝〉は、枝数が整数 值をとる場合にタイプI と判断できる要素であり、対母 屋柱比<奥行・向扯>が整数值をとる場合は、柱の直径 に依存しているタイプ II III、IVの判断要素となる。こ のうちタイプIIIは、向拝柱の直径を母屋柱の直径の $8 / 10$ にとっているので、整数とはならず、近似值に止まる。

この結果では、規矩尺集(2)の場合は、ாタイプで柱間 寸法を決定しているのに、垂木数が20であるから、2枝 $(\mathrm{L} \times 2 / 20)$ の数值之母屋柱の直径 $(\mathrm{L} \times 1 / 10)$ が等しく なり、数值上ではIタイプまたはIタイプのいずれかに 属すると判断される。<弥兵衛図>の場合も同様の理由 により、IタイプまたはIVタイプのいずれかに属すると 判断される。つまり、タイプを1つに絞れない場合（I または正、正、IVのいずれかに属すると判断される）は、 垂木数がMで、柱の直径が2L/Mとなるときである。

このように、数值から I、II、II、IVのタイプに属す るか否かの分類を武みると、設計側の意図がそのまま分 析できず、重複するタイプのいずれか判断しがたいもの が出てくる。これは、設計段階で他の設計法を内在して いるからである。したがって、数值からタイプを分類す ると、柱間決定法に内在するタイプ、あるいは柱間决定 法として採用された可能性のあるタイプが求められると いうことになる。そこで、改めて、

A：枝割型内在タイプ。

B : 内法心タ型内在タイプ。

C：内法外法型内在タイプ。

$\mathrm{D}$ ：母屋内法型内在タイプ。（適宜 $\mathrm{D}_{1} 、 \mathrm{D}_{2}$ を使用）

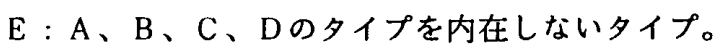
とタイプを設定する。

次に、表- 3 の柱間決定法に従って間口 1 尺の建築を 建て、この建物を実測した場合、誤差比率く $00.015>$ を想定しても表 -3 と同様の結果が得られるのか検討し た。表ー4は、この結果を柱間比率（間口に対する奥行 の比率）を小さい順に並べたものである。

表ー4では、〈対母屋柱比〉が誤差の範囲でく奥行と間 口との差〉、〈奥行と向拝奥行との差〉ともに1.0または 2.0 になるものに下線を記した。また、く枝差>の項目では、 間口の枝数に対して奥行・向拝奥行が何枝減らされてい るのかを検討し、誤差の範囲で〈奥行〉・〈向拝奥行〉共に 整数值を取ることができるものに下線を記した。この下 線を判断基準として、再度タイプ分類した。 


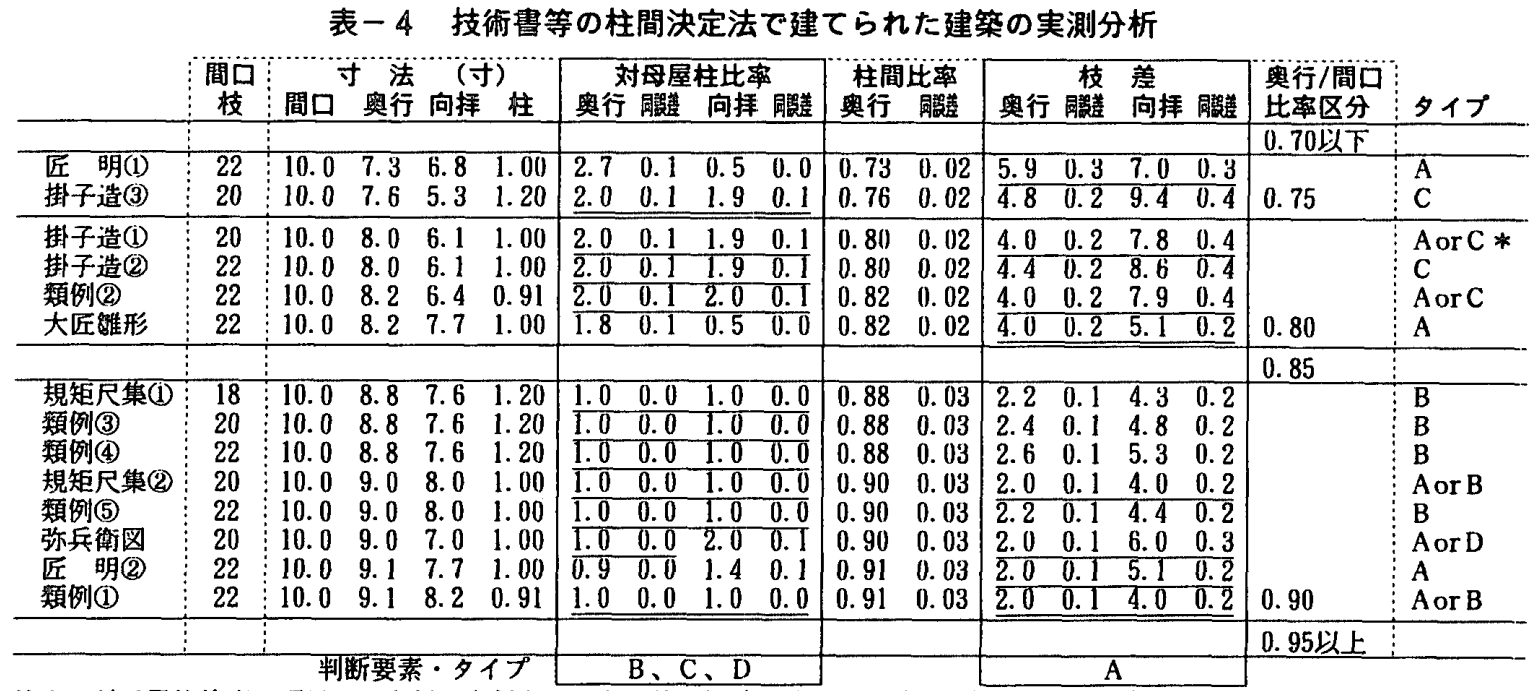

注 1 ：対母屋柱比㘁の項目 一 奥行は奥行と間口との差を柱寸で除した数值、向洋は奥行と向拝奥行との差を柱寸で除した数值。 柱間比率の項目 一 奥行は興行を間口寸法で除した数值を示す

枝差の項目一奥行は奥行枝数之間口枝数との差、向拝枝差は向拝奥行枝数と間口枝数との差を示す。

注 2 : 枝数の計算は、間口寸法を間口垂木数で割り、小数点以下第 4 位を四捨五入して得た寸法 $(S) を$ 用い (間口一奥行)/S、(間口一向拝舆行)/S、を計算した17)

また、誤差は、間口寸法と奥行寸法の差(誤差比は士0.03)を間口寸法(㖞差比は士0. 015)で除すので、 $+0.046 \geqq$ 実数比ミ-0.044となる。この表では誤差は実数比最大の0.046で融した数字を記した。 柱間比率区分では、0.87は0.85に、0.88と0.92は0.90に、0.93は0.95にそ机ぞれ算入した。

これによると、表ー3の段階で他の柱間決定法を内在 している場合を除くと、測定誤差によってタイプが判断 できないものは、く掛子造(1)〉である。これは、枝数割 りが測定誤差範囲にある（枝数割りが測定值で7.8であ り、測定誤差は最大土0.4となるので、枝数割り整数 8 がこの範团に含まれる）ためである。つまり、他の柱間 决定法に近似する値をとる場合にはタイプを1つに絞れ ないことになる。しかし、掛子造(1の方法で建てられた 建築を、<A or C >タイプの建築—と判断しても、そ こにはCタイプ（脚子造(1)）が含まれているので、表一 4 の分析は夕イプの特定に幅があっても、方法としては 誤りのないものと判断できる。

次に、間口に対する奥行の比率に着目すると、誤差範 囲内で比率0.80をとるタイプと比率0.90をとるタイプお よびその他の夕イプに大別できる。

比率が誤差内で0.80に属するタイプは、AまたはC 夕 イプの柱間决定法でこのうちAタイプは奥行寸法を間 口寸法より 4 枝分減らした寸法とする計画のものである ことがわかる。一方、比率が虽差内で0.90に属する夕イ プは、AまたはBタイプの决定法で、このうちAタイプ は奥行寸法を間口寸法より 2 枝分減らした寸法とする計 画のものであることがわかる。また、Dタイプのうち、 0.80に属するものは、間口に対する奥行柱間をく間口内 法＝奥行外法>にとるもの $\left(\mathrm{D}_{2}\right)$ であり、0.90に属する ものは、間口に対する奥行柱間をく間口内法＝奥行心々 >にとるもの( $\left.\mathrm{D}_{1}\right)$ ということになる。つまり、間口に 対する奥行の比率によって集計すれば、そこに内在する 具体的な内容（Aタイプの 4 枝分減らすなど）を把握す
ることが可能となる。

以上から、垂木数、母屋柱の直径、間口に対する奥行 の比率に着目すると、誤差範囲内で平面計画に内在する 柱間决定法を概如把挃できるものと判断される。

\section{4.一間社社殿の垂木数}

実測された社殿のうち、板軒のものおよび報告書等か らは垂木数が確認できないものを除いた180棟の建物に ついて、間口柱間に打たれた垂木の数を集計した（図一 1）。柱心に垂木を用いている場合は柱間の垂木数に 1 を加えた数字として処理した。なお、本繁垂木か㻋垂木 かなどの分類はせず、単純に垂木数にようて分析した。 愎屋のない本殿の場合、屋根草替が綠り返されるうちに、 垂木数が変更されることがある。葛山落合神社本殿の場 合は、当初20枝でったものが、後の修理で19枝に変更 されている ${ }^{18)}$ 。調查した近世社寺建築の中で、後世に 垂木割が変更されていると認められるもの（饰の痕跡や 支輪との取り合いなどから判定できるもの)については、 当初と考えられる垂木数を用いた。

この結果を時代別にまとめると、江戸前期までの建筑

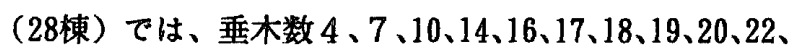
$24 、 26$ があり、垂木数 18 8 棟で最も多かった。

江戸中期前半の建築（35棟）では、垂木数 $14 \sim 17 、 18$ 、 19が減少し、代わって垂木数22が11棟に增加する。垂木 数20、21、22を合わせると18棟となり、この時代の半数 を越えている。江戸中期後半の建筑（38棟）では、垂木 数22が27棟と急增し、全体の71\%に達している。 
江戸後期の建築（61棟）では、垂木数22が40棟あり、 前時代と同様に、全体の過半数を占めている。

江戸末期・明治期の建築は18棟と調查事例が少ないが、 やはり垂木数22の割合が全体の過半数を占めている。

18世紀初頭までに出版された技術書では、『新編拾遗 大工規矩尺集』が垂木数18と20、『匠明』や『大匠雅形』 が垂木数22とされている。信濃の遺構をるると、江戸中 期前半までは垂木数に支配的な数は特定できない。しか し、江戸中期後半以降になると、上記技術書にみられる 垂木数18、20、22のいずれかをとる建築が全体の半数を 越える。そのうちであ、垂木数22をとる建築が支配的と なっている。伊藤弥兵衛の建地割図（享保17年）では垂 木数を 20 とするが、18世紀以降の事例では垂木数を $20 に$ とる建築は少数派で、『匠明』や『大匠觹形』に示され た垂木数を22にとる一間社が急速に增加したことがわか る。垂木数で見る限り、1つの数（垂木数22）への急激 な集中は、『大匠觹形』など垂木数を22にとる刊行本の 影響がかなり強かったためと推定される。

\section{5.一間社の柱間比率とタイブ}

次に、間口に対する奥行の比率を表 -4 之同様の方法 で集計した（図ー2）。これによると、誤差範团内で比 率0.80に属する建築は、江戸前期までは 3 割、江戸中期 前半では 2 割台に減少するが、江戸中期後半から江戸後 期では 4 割台を維持している。

比率0.90に属する建筑は、江戸前期までは 3 割台、江 戸中期前半では 4 割台に增加するが、江戸中期後半から 江戸後期では 3 割台に減少している。

時代的にみると、江戸中期前半が、他の時代と異なっ た分布を示している。江戸中期後半以降は、比率0.80と 0.90 とで過半を占め、比率0.80と0.90との比較では、0. 80 の方が棟数で優位を占めている。

設定したタイプへの属性の分布(図ー3)をみると、A タイプに属する割合は江戸中期までは 1 割台で、江戸後 期になって2割を越えている。一方、B、C、Dタイプ に属する割合は、江戸中期前半までは 3 .割台であるが、 江戸中期後半からは 1 割程度となる。 $\mathrm{E}$ タイプは、どの 時代でも 4 割程度は存在している。

こうした比率を、一間社 153棟の実測を報告している 神奈川県 ${ }^{19}$ と比輘（図一-4）してみる。神奈川県では 江戸中期前半には、比率0.80が5割台、0.90が2 割台て あるが、江戸中期後半では、0.80、0.90が共に 3 割台と なり、江戸後期は、0.80が 2 割台、0.90が 4 割台となっ ている。江戸中期前半では0.80が過半であるが、中期後 半からは 0.90 が棟数で優勢となっている。

これをみると、柱間比率の分布は、地域や時代によっ て異なっていること、技術書が刊行されても、活羅した
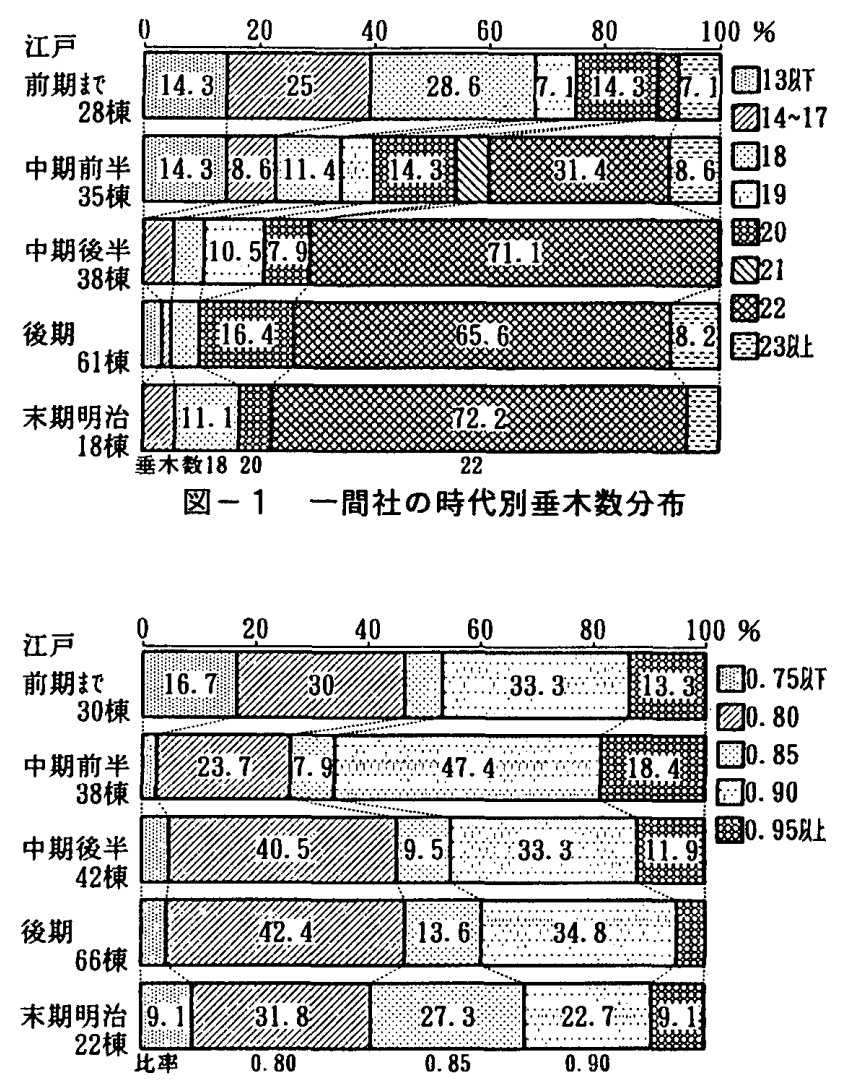

図一２時代別柱間比率(奥行/間口此率による)

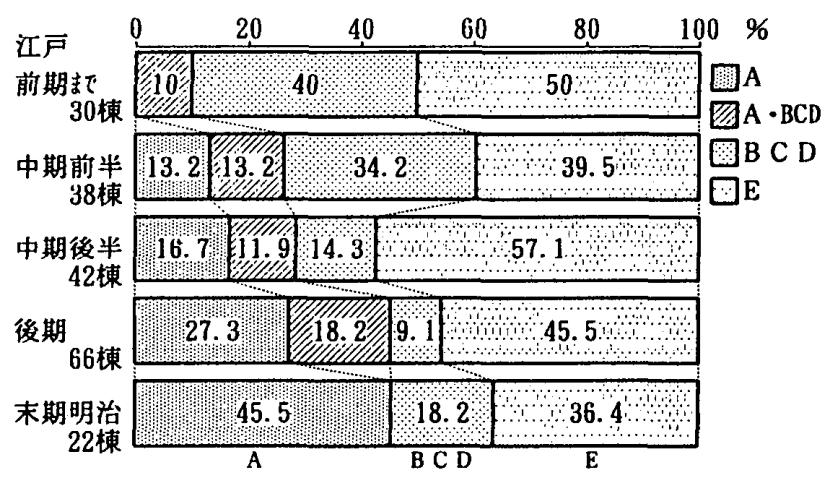

図ー3 時代別柱間決定法タイプ

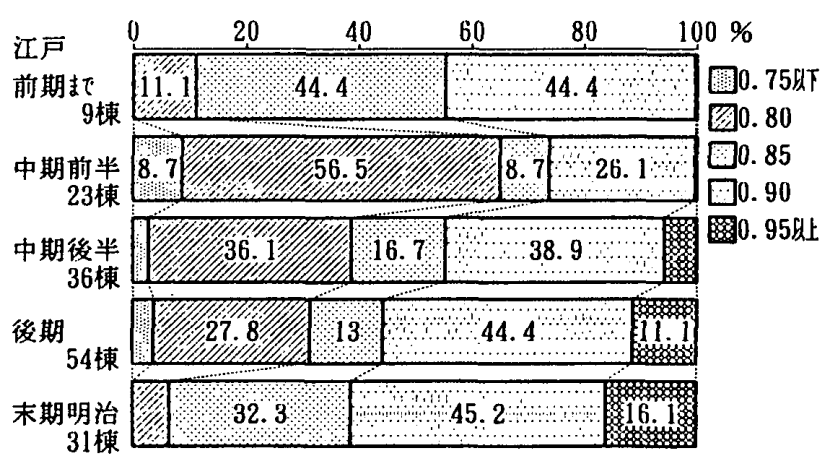

図-4 神奈川県の時代別柱間比率(奥行/間口) (一間社) 
表 -5 信濃の一間社 柱間決定法分析一篦

\begin{tabular}{|c|c|c|c|c|c|c|c|c|c|c|c|c|c|c|c|}
\hline （江戸前期まで） & 所在地 & 潇筑年代 & & & 奥淩 & $\begin{array}{l}\text { (寸) } \\
\text { 向择 }\end{array}$ & 䘄柱 & 䀅害息 & 欍篗 & 奥行 & 奥㟚 & 向据 & 医 名 & 文献 & 912 \\
\hline 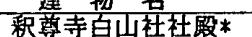 & 禾墸蒂 & 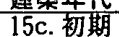 & $\frac{18}{18}$ & 35.1 & $\frac{240}{24.3}$ & $\frac{10.7}{16.1}$ & & & & & 5.5 & $\frac{15+7}{9.7}$ & & 県筻 & -6 \\
\hline 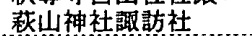 & 高林町 & 承店 2 年 & 22 & 67.5 & 47.5 & 43.4 & 6.93 & 2.9 & 0.6 & 0.70 & 6.5 & 7.9 & & 1 次 & \\
\hline 籍嗨社東本社 & 兒田町 & 室町中期 & 24 & 91.2 & 70.5 & 51.1 & $7.10^{\circ}$ & 2.9 & 2.7 & 0.77 & 5.4 & 10.6 & & 㽦穻 & EO \\
\hline 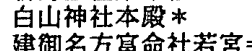 & 飯山市 & 席永 32 年 & $\begin{array}{r}20 \\
9\end{array}$ & 20.0 & $\begin{array}{l}15.0 \\
46.3\end{array}$ & 18.6 & 2. 21 & 2.3 & $\begin{array}{r}-1.6 \\
1.2\end{array}$ & 0.75 & 5.0 & 1.4 & & 王事 & 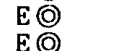 \\
\hline 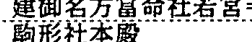 & 掔山市 & 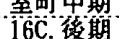 & 17 & $\begin{array}{l}0.1 .2 \\
30.0\end{array}$ & $\frac{40.3}{234}$ & $\begin{array}{l}40=0 \\
28.7\end{array}$ & .5. 30 & $2: 0$ & $\begin{array}{c}1.2 \\
-1.6 \\
\end{array}$ & $\begin{array}{l}0.78 \\
0.78\end{array}$ & $\frac{4}{3.8}$ & 0.1 & & I事 & $\begin{array}{l}E(Q) \\
\mathrm{D}\end{array}$ \\
\hline 泃形神社本殿 & 佐久市 & 室町後期 & 20 & 49.9 & 39.9 & 33.7 & & & & 0.80 & 4.0 & 6.5 & & 工事 & -(a) \\
\hline 八皤神社莭訪社 & 阿南町 & 永正 3 年 & 18 & 50.2 & 39.4 & 36.2 & 5.50 & 2.0 & 0.6 & 0.78 & 3.9 & 5.0 & 吉村与惣右衛門 & 工事 & A or D \\
\hline 八幡神社本毁 & 阿南町 & 永正 3 年 & 18 & 53. 3 & 42.2 & 43.2 & 5. 50 & 2.0 & -0.2 & 0.79 & 3.8 & 3.4 & 吉村与物右盛門 & 圭事 & D \\
\hline 大山田神社応神社 & 下条村 & 永正 3 年 & 18 & 53.1 & 42.6 & 42.6 & 5.28 & 2.0 & 0.0 & 0.80 & 3.6 & 3.6 & 吉村与忽右衛門 & 国宝 & D () \\
\hline 社為朝社 & 下条村 & 鹿安元年 & 18 & 53.1 & 42.5 & 42.3 & 5.28 & 2.0 & 0.0 & 0.80 & 3.6 & 3.7 & & 国宝 & D@ \\
\hline 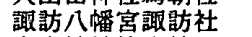 & 泰皁村 & 元鼠 4 年 & 板 & 40.2 & 31.8 & 25.0 & 3. 99 & 2.1 & 1.7 & 0.79 & - & - & 茄原丹波守 & 県更 & D \\
\hline 白山神社境内社= & 大桑村 & & 4 & 32.1 & 25.6 & 17.8 & 3.40 & 1.9 & 2.3 & 0.80 & 0.8 & 1.8 & & 国宝 & D \\
\hline 白山秆社本毁= & 大桑村 & 元弘 4 年 & 10 & 33.0 & 26.6 & 17.6 & 3.50 & 1.8 & 2.6 & 0.81 & 1.9 & 4.7 & 七郎橋宗重 & 国富 & \\
\hline 若一䇮子神社本毁 $*$ & 犬町市 & 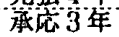 & 19 & 81.7 & 68.8 & 61.4 & $9.50^{\circ}$ & 1.4 & 0.8 & 0.84 & 3.0 & 4.7 & 金原周防 & 畺害 & Ë() \\
\hline 建製名方富命社本堅 & 飭山芇 & 宽水20年 & 18 & 64.8 & 55.0 & 49.7 & 6.11 & 1.6 & 0.9 & 0.85 & 2.7 & 4. 2 & 長右街門 & 県更 & $\mathrm{E}$ \\
\hline 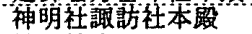 & 白馬村 & 笑正16年 & 16 & 34.9 & 30.6 & 22.0 & $4.19^{\circ}$ & 1.0 & 2.1 & 0.88 & 2.0 & 5.9 & 金愿䓟 & 茴宝 & $\mathrm{A}$ or $\mathrm{D}$ \\
\hline 社本展 & 白馬村 & 天正16年 & 10 & 35.3 & 31.2 & 24.2 & 4.19 & 1.0 & 1.7 & 0.88 & 1.2 & 3.1 & & 国宝 & \\
\hline 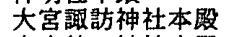 & 小谷村 & 完和 5 年 & 14 & 48. 1 & 43.0 & 35.7 & 5. 28 & 1.0 & 1.4 & 0.89 & 1.5 & 3.6 & 金原周防守歎 & 県史 & D \\
\hline 田神社本殿 & 梓川村 & 室町後期 & 20 & 60.0 & 53.0 & 39.7 & 7.00 & 1.0 & 1.9 & 0.88 & 2.3 & 6.8 & & 工事 & DO \\
\hline & 梓川村 & 室町後期 & 14 & 40.3 & 35.7 & 25.6 & 4. 59 & 1.0 & 2.2 & 0.89 & 1.6 & 5.1 & & 工事 & D@) \\
\hline 宇賀神 & 信湛町 & 莌永 5 年 & 17 & 50.5 & 44.6 & 41.9 & 5.78 & 1.0 & 0.5 & 0.88 & 2.0 & 2.9 & & 2次 & A or D \\
\hline 白琵 & 鬼無里村 & 江户前期 & 16 & 45.6 & 40.6 & 36.1 & 5. 05 & 1.0 & 0.9 & & 1.8 & 3.3 & & 県史 & \\
\hline 南方 & 户隠村 & 桃山時代 & 14 & 30.7 & 27.5 & 21.3 & 3. 40 & 0.9 & 1.8 & 0.90 & 1.5 & 4.3 & & 県吏 & $\mathrm{E}$ \\
\hline 武水別神社高良社= & 更埴市 & 室町後期 & 板 & 46.0 & 41.2 & 36.0 & 4. 29 & 1.1 & 1.2 & 0.90 & - & - & & 県史 & $\mathrm{E}($ \\
\hline 佐野神社本殿 & & 天正20年 & 19 & & 50.7 & 50.4 & 5.45 & 1.0 & 0.1 & 0.91 & 1.8 & 1.9 & 宮崎圭 & 梨事 & $D @$ \\
\hline 穼島神社本殿 & 㰺山市 & 方治 2 年 & 18 & 64.4 & 60.2 & 47.4 & 5.68 & 0.7 & 2.3 & 0.93 & 1.2 & 4.8 & 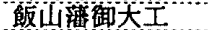 & 飯山 & $\mathrm{E}$ \\
\hline 生島足島神社䛵訪社 & 上笛市 & 鹿食占年 & $26^{\circ}$ & 92.8 & 93.6 & 86.6 & & & & 1.01 & $0 . \hat{2}$ & 1.7 & 篙嵀勘西郎 & 算莄 & 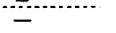 \\
\hline 山落合神社本殿*- & 長野市 & 莌正 6 年 & 20 & 62.0 & 62.0 & 46.5 & 7. 00 & 0.0 & 2.2 & 1.00 & 0.0 & 5.0 & せんさえもん & 工事 & $\mathrm{E} @$ \\
\hline 葛 & 長野市 & 室町後期 & 18 & 35.1 & 39.0 & 30.8 & 3.73 & -1.0 & 2.2 & 1.11 & 2.0 & 2.2 & & 県史 & $\mathrm{E}(\mathrm{O})$ \\
\hline (IIJ中期前半) & & & & & & & & & & & & & & & \\
\hline 岩下十二神社本殿= & 奥無蝫村 & 17C.中期 & 板 & 9.7 & 7.2 & 4.6 & 1.29 & 1.9 & 2.0 & 0.74 & - & - & & 鬼無 & C. \\
\hline 社中本社 & 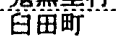 & 光禄了3年 & 23 & 94.1 & 74.3 & 60.4 & 7.79 & 2.5 & 1.8 & 0.79 & 4.8 & 8.2 & (kib)佐兵衡 & 1 次 & $\ddot{A}$ \\
\hline 社本 & 北御牧村 & 17c. 末期 & 18 & 29.4 & 23.4 & 20.1 & & & & 0.80 & 3.7 & 5.7 & & 1 坎 & - \\
\hline 社* & 佐久市 & 元禄统 & 22 & 60.0 & 48.6 & 45.2 & 5.68 & 2.0 & 0.6 & 0.81 & 4.2 & 5.4 & & 実測 & D \\
\hline & 伊那市 & & 22 & 53. 9 & 42.2 & 40.3 & & 2.2 & 0.4 & & 4.8 & 5.6 & & & $\mathrm{E}$ \\
\hline & 飯田市 & 延宝 6 年 & 22 & 70.3 & 57.7 & 53.6 & 7. 29 & 1.7 & 0.6 & 0.82 & 3.9 & 5.2 & 林吉与 & 1 坎 & $\tilde{A}$ \\
\hline & 塩㞔市 & 莌文12年 & 10 & $75: 3$ & 60.1 & 44.8 & 7. 39 & 2.1 & 2.1 & 0.80 & 2.0 & 4.1 & 中村四郎 & 1 次 & A or C \\
\hline & 塩尻市 & 寞文12年 & 22 & 86. 2 & 70.6 & 55.8 & 8.81 & 1.8 & 1.7 & 0.82 & 4.0 & 7.8 & 中村四郎右衛門 & & \\
\hline 社香取社 & 大桑树 & 延宝 3 年 & 20 & $36: 3$ & 29.7 & 25.7 & $\begin{array}{l}\text { 3. } 30 \\
\text { 3. }\end{array}$ & 2.0 & 1. 2 & 0.82 & 3.6 & 5.8 & 4九吉兵徫( & 1 次 & D \\
\hline 溶)本殿 & 皇馬村 & 宽文 & 22 & & 28.9 & 27.2 & 3.63 & 1.7 & 0.5 & 0.82 & 3.9 & 5.0 & 椣田右近大桠 & 奏㵋 & A \\
\hline & 稩们树 & 筧文 4 年 & 22 & 63.2 & 52.4 & 45.0 & 5.94 & 1.8 & 1.2 & & 3.8 & 6.3 & 垥崖 & & $\mathbf{E}$ \\
\hline 社八坂社= & 些郷村 & 17c. 後期 & 20 & 44.9 & 37.1 & 34.3 & 3. 89 & 2.0 & 0.7 & & 3.5 & 4.7 & & 実眻 & D \\
\hline & 治田町 & & 10 & & 37.9 & & 5.28 & 1.0 & 0. & 0.87 & 1.3 & 2.1 & & & D. \\
\hline & 䈨野等 & 延宝6年 & 板 & & 28.1 & & & $1.0^{\circ}$ & 0 . & & & - & 新村能之水 & 首史 & $\overline{\mathrm{D}}$ \\
\hline 大神宮 & 佐久市 & 延首頃 & 20 & 42.3 & 37.7 & 3 & 4. 29 & 1.1 & 0.6 & 0.89 & 2.2 & 3.3 & & 実溉 & D \\
\hline & 立科 & & 18 & & 45.2 & 46.4 & 5.60 & 0.9 & -0.2 & 0.90 & 1.8 & 1.4 & & 1 次 & E \\
\hline & & & 19 & 30.4 & 27.4 & 27.1 & 3. 07 & 1.0 & & 0.90 & 1.9 & 2.1 & & 実測 & A or D \\
\hline & & & 21 & 54 & 49.6 & 44.0 & 5. 35 & 1.0 & 1.0 & 0.91 & 2.0 & 4.1 & & 奉测 & $A$ or $B$ \\
\hline & 辰野 & & 22 & 71.0 & 63.4 & 54.3 & 7.2 & 1.0 & 1. & & 2.4 & 5. 2 & （加）滕原金三郎 & 1 次 & D \\
\hline & & 17c. 後半 & 6 & 34.6 & 31.1 & 26.9 & 3. 3 & 1.1 & & 0.90 & 0.6 & 1.3 & & 奏測 & D \\
\hline 本殿 & 伊那市 & 年間 & 21 & 60.0 & 54.3 & 43.4 & 5.94 & 1.0 & 1. & 0.91 & 2.0 & 5.8 & & 害爵 & A or D \\
\hline & 松本市 & & 19 & & 38.7 & 36.5 & 4. 29 & 1.0 & 0. & 0.90 & 1.9 & 2.9 & 中村四郎右衛門 & 工事 & A or D @ \\
\hline & & & & 41 & 37.0 & 24. & & 1. & 3.2 & 0.90 & & & & & D \\
\hline & & & 14 & & 68. & 44. & 7.9 & 0. & 3.0 & 0.91 & 1.3 & 5.8 & & 県史 & E \\
\hline 本殿- & & & 8 & 49 & 44.7 & 41.6 & 5.5 & 0.8 & 0. & & & 1. & & 1 & E \\
\hline & 坂城 & 真早 5 年 & 22 & 72.6 & 64.7 & 64.7 & & & & & 2.4 & 2.4 & & 1 次 & - \\
\hline 主本殿- & & & 22 & & & 49.1 & & 1.0 & 0. & & 2.2 & 4. & & & \\
\hline & & & 20 & & 27. & & & & & & 2. & & & & D \\
\hline & 高山村 & 17c. 末期 & 18 & 45. & 40.1 & 35.5 & 4. 69 & 1.1 & 1. & 0.89 & 2.1 & 3.9 & & 悬史 & B \\
\hline & 須坂市 & & 22 & & 27.7 & 21.7 & & 0.7 & & & 1.7 & 6.1 & & & $\mathbf{E}$ \\
\hline & 中策 & & 8 & & 54.6 & 48. 6 & 6.60 & 0.7 & 0.9 & 0.9 & 0.6 & 1.4 & & 奏测 & E \\
\hline 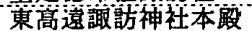 & 高逼町 & & 25 & 72. & 69.3 & 62.4 & 6.93 & 0.5 & 1.0 & 0.95 & 1.1 & 3.5 & & 次 & E \\
\hline & & & 17 & & & & & & & & & & & & \\
\hline & & & 16 & & 33. & 26 . & & & & & 0.9 & & & & \\
\hline 大元神社本殿 & 木島平杭 & 莌文元年 & 18 & 43.2 & 40.9 & 37.9 & & & & & 1.0 & $\begin{array}{l}4.1 \\
2.2\end{array}$ & 磷木与 & 真串 & - \\
\hline 北 & & & 23 & & 52.6 & 49.9 & 5.12 & 0 & 0. & & 1.4 & 2.5 & 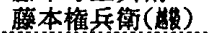 & 県史 & E \\
\hline 社贸宮 & 佐久门 & 莚瑩 & 20 & & 37.5 & 35.2 & 4.1 & 0.2 & & & 0.5 & 1.7 & & 实㴭 & $\mathrm{E}$ \\
\hline 若宮神社天満宮＊ & 佐久市 & 元蒜頃 & 22 & 60.0 & 71.0 & 46.7 & 5.78 & -1.9 & 4.2 & 1.18 & 4.0 & 4. 9 & & 奏湘 & A \\
\hline
\end{tabular}

注 i ) 愐目の略号一対母屋柱比 奥差：奥行寸法と間口寸法の差を柱寸で除した数值、同 向择差：奥行寸法と向择奥行寸法の差を

柱寸で除した数值、舆行/間口：奥行寸法/間口寸法、奥行枝差・向择枝差：表一4の枝荎に同し。

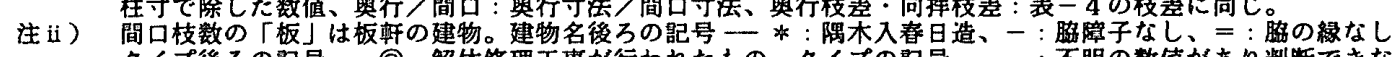

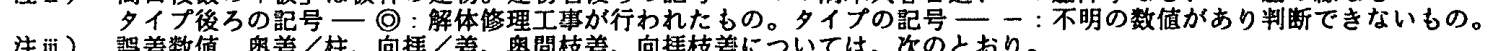

$$
\begin{array}{llll}
0.0 \sim 1.0 & \text { は䛇差 } \pm 0.0 & 1.1 \sim 3.2 \text { は譔差 } \pm 0.1 & 3.3 \sim 5.4 \text { は誤差 } \pm 0.2
\end{array}
$$

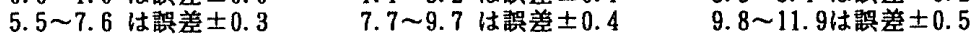

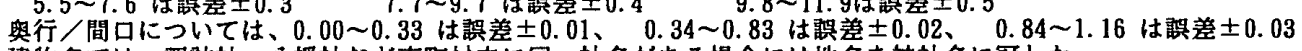

注iv）建物名では、部斿社・八幡社など市町村内に同一社名がある場合には地名を神社名に冠した。

また、表では宗教法人名溥によって確認できる篹囲内で神社名を略称した。

注 $\mathrm{i} \sim \mathrm{v}$ は表 $-5 \sim 6$ に共通。 
表-6 信濃の一間社 柱間決定法分析一臨（続き）

\begin{tabular}{|c|c|c|c|c|c|c|c|c|c|c|c|c|c|c|c|}
\hline [戸建中期後娄) & 所在地 & 建築年代 & 間口 & 間口 & 奥怯 & $\begin{array}{l}\text { (寸) } \\
\text { 向据 }\end{array}$ & 桂 & 奥差 & 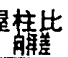 & 舞行 & 奥技 & 向据 & & 文嗝 & タイプ \\
\hline $\begin{array}{l}\text { 萩山神社八幡社 } \\
\text { 足长神社本殿 }\end{array}$ & $\begin{array}{l}\text { 高禾町 } \\
\text { 諏訪市 }\end{array}$ & $\begin{array}{l}\text { 草保14年 } \\
\text { 18C. 前期 }\end{array}$ & 22 & $\begin{array}{l}67.3 \\
50.2\end{array}$ & $\begin{array}{l}47.5 \\
36.0\end{array}$ & $\begin{array}{l}43.7 \\
33.6\end{array}$ & $\begin{array}{l}6.93 \\
5.54\end{array}$ & $\begin{array}{l}2.9 \\
2.6\end{array}$ & $\begin{array}{l}0.5 \\
0.4\end{array}$ & $\begin{array}{l}0.71 \\
0.72\end{array}$ & 6.5 & 7.7 & 坂巻新兵衛(鼠田) & $\begin{array}{l}1 \text { 次 } \\
2 \text { 次 }\end{array}$ & $\begin{array}{l}\mathrm{E} \\
\mathrm{E}\end{array}$ \\
\hline 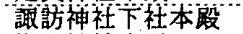 & 八午穂村 & 正徳 5 年 & & 56.1 & 44.6 & 40.5 & 5.28 & 2.2 & 0.8 & 0.80 & & & 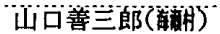 & 论 & E \\
\hline 塩野神社本殷 & 上田市 & 寬延 3 年 & 22 & 80.0 & 65.5 & 59.0 & 7.92 & 1.8 & 0.8 & 0.82 & 4.0 & 5.8 & 末野忠兵衛 (上时) & 2 次. & A \\
\hline 八幡神社本哣 & 和田村 & 18c. 前期 & 22 & 34.0 & 27.9 & 26.1 & 4.06 & 1.5 & 0.4 & 0.82 & 3.9 & 5.1 & & 1 次 & A \\
\hline 表貫諏訪社本殿 & 佐久市 & 宝永 8 年 & 22 & 50.6 & 41.4 & 39.1 & 4.95 & 1.9 & 0.5 & 0.82 & 4.0 & 5.0 & 依田文七郎知重 & 実测 & A or D \\
\hline 耶田八幡神社天数宫＊ & 佐久市 & 元文頃 & 22 & 26.5 & 21.7 & 20.4 & 3. 00 & 1.6 & 0.4 & 0.82 & 4. 0 & 5. 1 & & 実測 & \\
\hline 近津神社本殷 & 佐久市 & 宝水 & 22 & 94.6 & 77. 9 & 73.5 & 8.58 & 1.9 & 0.5 & 0.82 & 3.9 & 4. 9 & & 文書 & A or D \\
\hline 根神社本殿* & 望月町 & 龺保ころ & 22 & 37.0 & 30.5 & 29.6 & 3.96 & 1.6 & 0.2 & 0.82 & 3.9 & 4.4 & & 実测 & \\
\hline 山家神社子安社 & 真田町 & 享保15年 & & 43.6 & 34.7 & 39.6 & & & & 0.80 & & & 牧野平六（上略大I） & 1 次 & E \\
\hline 八幡社本殿 & 富士見町 & 寛保元年 & 22 & 37.4 & 30.3 & 29.2 & 3.70 & 1.9 & 0.3 & 0.81 & 4. 2 & 4.8 & & 2 次 & D \\
\hline 八幡社本殿 & 岡谷市 & $18 \mathrm{c}$. 前期 & 22 & 60.4 & 49.5 & & 5.94 & 1.8 & 8.3 & 0.82 & 4.0 & - & & 1 次 & E \\
\hline 鹿頭神社本殿 & 松本市 & 正徳 5 年 & 22 & 70. 6 & 58.1 & 44.6 & 7. 26 & 1.7 & 1.9 & 0.8 & 3.9 & 8. 1 & 渡辺元右衛門(䀰) & )実湘 & A \\
\hline 公幡宮本殿 & 上松町 & 正徳 4 年 & 22 & 38.8 & 31.7 & 26.7 & 3.80 & 1.9 & 1.3 & 0.82 & 4. 0 & 6. 9 & 田中儀兵衛(融) & 2 次 & A or D \\
\hline 林千鹿頭社本殿 & 松本市 & 元文 5 年 & 22 & 70.4 & 57.8 & 50.7 & 7.49 & 1.7 & 0.9 & 0.82 & 3.9 & 6.2 & 中根弥七(睢) & 実湘 & A \\
\hline 神社本殿 & 塩宥市 & 真保 3 年 & 20 & 62.1 & 49.1 & 38.8 & 5.94 & 2.2 & 1.7 & 0.79 & 4.2 & 7.5 & 忠兵衛（锥大I） & 塩究 & $\mathrm{E}$ \\
\hline 飯森神社本殷 & 白馬村 & 享保頃 & 22 & 25.1 & 20.1 & 18.5 & 2.81 & 1.8 & 0.6 & 0.80 & 4.4 & 5.8 & & 実测 & $\overline{\mathrm{E}}$ \\
\hline 衣更着神社氏神社 & 木祖村 & 18c. 前期 & 22 & 31.5 & 25.1 & 24.4 & 3. 96 & 1.6 & 0.2 & 0.80 & 4.5 & 5.0 & & 実湘 & $\mathrm{E}$ \\
\hline 童津噇神社本殿 & 飯山市 & 元文2 年 & 22 & 36.8 & 28.7 & 27.9 & 4. 09 & 2.0 & 0.2 & 0.78 & 4. 9 & 5.3 & & 飲山 & D \\
\hline 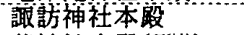 & 節树 & 延豙年 & 22 & 60.1 & 50.0 & 45.6 & 5.68 & 1.8 & 0.8 & 0.83 & 3.7 & 5.3 & 手島勝右衛門 & 実測 & $\mathrm{E}$ \\
\hline 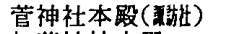 & 白嘕村 & 享保 5 年 & 22 & 25.7 & 21.5 & 18.9 & 2.64 & 1.6 & 1.0 & 0.84 & 3.6 & 5.8 & 横田宮内匠 & 実测 & $\mathrm{E}$ \\
\hline $\begin{array}{l}\text { 加茂神社本殿 } \\
\text { 耐羽神社本殿 }\end{array}$ & $\begin{array}{l}\text { 鬼無里村 } \\
\text { 北御牧村 }\end{array}$ & $\begin{array}{l}\text { 元文延豙 } \\
\text { 宝永 } 2 \text { 年 }\end{array}$ & 22 & $\begin{array}{l}35.0 \\
51.5\end{array}$ & $\begin{array}{l}28.9 \\
44.6\end{array}$ & $\begin{array}{l}27.7 \\
39.6\end{array}$ & 4. 03 & 1.5 & 0.3 & $\begin{array}{l}0.83 \\
0.87\end{array}$ & 3.8 & 4.6 & & 鬼無 & $\begin{array}{l}\mathrm{E} \\
\mathrm{E}\end{array}$ \\
\hline 新町媩訪社本殿= & 辰野町 & 18c. 前期 & 22 & 66.7 & 58.6 & 52.2 & 6.93 & 1.2 & 0.9 & 0.88 & 2.7 & 4.8 & & 1 㳄 & E \\
\hline 池生神社本殿 & 富士見町 & 享保年間 & 17 & 30.5 & 26.9 & 25.0 & 3.47 & 1.0 & 0.5 & 0.88 & 2.0 & 3. 1 & & 2 次 & A or D \\
\hline 平尼大社本殿 & 佐久市 & 18C. 前期 & 22 & 51.7 & 46.2 & 41.1 & 4.95 & 1.1 & 1.0 & 0.89 & 2.3 & 4.5 & & 2 次 & B \\
\hline (幡神社本殿 & 佐久市 & 宝水元年 & 22 & 42.9 & 38.4 & 33.3 & 4. 19 & 1.1 & 1.2 & 0.9 & 2.3 & 4.9 & 土屋伊右箈 & 実测 & D \\
\hline 申社本殿 & 望月町 & 享保ころ & 22 & 55.2 & 49.5 & 43.8 & 5. 31 & 1. 1 & 1.1 & 0.9 & 2.3 & 4.5 & （佐久系） & 実恻 & B \\
\hline 社本殿 & 東部町 & 宝永 4 年 & 22 & 35.0 & 31.8 & 23.1 & 3.47 & 0.9 & 2.5 & 0.9 & 2.0 & 7.5 & & 1 次 & $\mathrm{E}$ \\
\hline & 辰野町 & 18c. 前期 & 22 & 32.0 & 28.9 & 25.9 & 3.96 & 0.8 & 0.8 & 0.90 & 2.1 & 4.2 & 丸山生左衛門 & 実测 & A \\
\hline 申社本殿 & 辰野町 & 享保 2 年 & 22 & 60.1 & 53.9 & 49.1 & 6.93 & 0.9 & 0.7 & 0.90 & 2.3 & 4.0 & 丸山庄左衛門 & 実渭 & $\mathrm{E}$ \\
\hline 八幡社本殿 & 辰野町 & 18c. 前期 & 22 & 37.4 & 34.0 & 30.1 & 4. 79 & 0.7 & 0.8 & 0.91 & 2.0 & 4.3 & 丸山庄左衙門 & 実測 & E \\
\hline 吉野神社本殷㽢高部策 & 豊科町 & 宝永 6 年 & 14 & 75.8 & 68.8 & 43.6 & 7.82 & 0.9 & 3.2 & 0.91 & 1.3 & 5.9 & & 県史 & $\mathrm{E}$ \\
\hline 天満社本殿 & 飯山市 & 豙保12年 & 18 & 45.4 & 40.3 & 36.9 & 4. 69 & 1. 1 & 0.7 & 0.89 & 2.0 & 3.4 & 小林仁兵衛 & 飯山 & D \\
\hline 社本殿 & 飯山市 & 豙保年間 & 18 & 35.1 & 31.7 & 29.8 & 4.22 & 0.8 & 0.5 & 0. & 1.7 & 2.7 & & 飯山 & $\mathrm{E}$ \\
\hline 申社本殿 & 栄村 & 正徳元年 & 20 & 50.0 & 45.0 & 48.3 & 5.28 & 0.9 & -0.6 & 0.90 & 2.0 & 0.7 & 藤本権兵 & 2次 & $\mathrm{E}$ \\
\hline C & 主滰村 & 辛保年間 & 22 & 19.7 & 18.2 & 14.2 & 1.98 & 0.8 & 2.0 & 0.92 & 1.7 & 6.1 & & 2次 & $\ddot{\mathrm{E}}$ \\
\hline 神社中営* & 八手穂村 & 元文 4 年 & 19 & 40.1 & 43.2 & 36.5 & 4.13 & -0.8 & 1.6 & 1.08 & 1.5 & 1.7 & 小泉吉右衛 & 2 次 & $\mathrm{E}$ \\
\hline 社南宮* & 八千穂村 & 元文 4 年 & 19 & 40.1 & 43.2 & 36.5 & 4.13 & -0.8 & 1.6 & 1.0 & 1.5 & 1.7 & 小泉吉右衛 & 2 & $E$ \\
\hline 新宮* & 八千穂村 & 元文 4 年 & 19 & 40.1 & 43.2 & 36.5 & 4.13 & -0.8 & 1.6 & 1. & 1.5 & 1.7 & 小泉吉右徫 & & $\mathrm{E}$ \\
\hline 喑能野神社本殿* & 望月町 & 享保ころ & 19 & 40.3 & 44.6 & 36.1 & 4.29 & -1.0 & 2.0 & 1. & 2.0 & 2.0 & （佐久系） & 実測 & A or D \\
\hline 金峯山神社本殷 & 川上村 & 宝永 4年 & 20 & 46.0 & 51.5 & & & -1.1 & 2.0 & 1.1 & & 1.9 & & & \\
\hline (江戸後期抜粋) & & & & & & & & & & & & & & & \\
\hline 田本神社都訪社 & 泰卓树 & 文化 & 28 & 50.4 & 32.7 & 30.6 & 4.2 & 4.2 & 0.5 & & 9.8 & 11.0 & 杉山市良 & & A or D \\
\hline 八幡神 & 富士見町 & 宝糜13年 & 24 & 51.7 & 34.7 & 37.3 & 4. 62 & 3. 7 & -0.6 & 0.6 & 7.9 & 6.7 & 加藤 & 1 次 & \\
\hline 酦钫社本殿 & 堀金村 & 文化 7年 & 22 & 51.1 & 36.3 & 33.5 & 5.38 & 2.8 & 0.5 & & 6.4 & 7.6 & 小七武 & 奏測 & $E$ \\
\hline 社本殿 & 箕輪町 & 文化 5 年 & 20 & 60.0 & 48.0 & 45.2 & 6. 90 & 1.7 & 0.4 & a & 4.0 & 4.9 & 立们富香o & 奏朗 & A \\
\hline 八幡社本殿 & 茅野市 & 文政 8 年 & 22 & 23.1 & 18.8 & 17.8 & 2.57 & 1.7 & 0.4 & 0.8 & 4.1 & 5.0 & 立川和四追 & 2 次 & A \\
\hline 殿 & 塩㞔市 & 文化14年 & 22 & 55.1 & 45.3 & 40.5 & 5.94 & 1.6 & 0.8 & 0. & 3.9 & 5.8 & 立川和匹 & 塩 & A \\
\hline 本殿 * & 駒ヶ根市 & 文政12年 & 22 & 72.6 & 59.4 & 55.9 & 6. & 1.9 & 0.5 & & 4.0 & 5.1 & 楊昌 & 1 & A or D \\
\hline 般 & 辰野町 & 文政 & 22 & 53.5 & 43.4 & 40.9 & 5.5 & 1.8 & 0.5 & & 4. 2 & 5.2 & 小口 & 実湘 & A \\
\hline 手社本殿 & 南箕輪村 & 文政12年。 & 22 & 60.1 & 49.0 & 46.8 & 6. 93 & 1.6 & 0.3 & & 4.1 & 4.9 & 小口㨁民 & 2 次 & A \\
\hline & 箕輪町 & 宽政 9 年 & 22 & 83.5 & 67.8 & 65.1 & 8.0 & 1. 9 & 0.3 & & 4.1 & 4.8 & 閏矩重 & & A or D \\
\hline 訪社 & 塩民市 & 天明 2 年 & 22 & 79.0 & 64.0 & 61.0 & 7. 92 & 1.9 & 0.4 & 0. & 4.2 & 5.0 & 柴? & 県史 & A or D \\
\hline 社本殷 & 箕輪町 & 寞政 9 年 & 22 & 71.6 & 58.6 & 51.8 & 7.00 & 1.9 & 1.0 & 0.8 & 4.0 & 6.1 & 柴? & 実测 & A or D \\
\hline 神社本殿 & 戸會町 & 寛政元年 & 22 & 100.0 & 81.8 & 76.1 & & & & 0.8 & 4.0 & 5.3 & 柴宮王 & 県史 & A - \\
\hline 天王社本殿 & 麻綃村 & 文政 6 年 & 22 & 48.0 & 38.9 & 37.1 & 5.45 & 1.7 & 0.3 & & 4.2 & 5.0 & 藤森。 & 実 & A \\
\hline & 富士見町 & 文政 2 年 & 22 & 37.9 & 31.1 & 27.6 & 3.80 & 1.8 & 0.9 & & 4.0 & 6.0 & 小池佐占 & 2 & A \\
\hline 社本殿 & 伊那市 & 宝暦11年 & 22 & 38.6 & & & 4.2 & 1.7 & 0.3 & & 4. & 5.0 & & 1 次 & A \\
\hline 大哩 & & 天明元年 & 22 & 60.4 & 48.8 & 46.6 & 6.2 & 1.9 & 0.4 & & 4. 2 & 5.0 & & & A or D \\
\hline 木 股 & 辰野町 & 宝魔 4 年 & 22 & 35.8 & 29.0 & & 4. 2 & 1.6 & 0.0 & & 4.2 & 4. 2 & 井讯偖左铲 & & A \\
\hline 社本殿 & 茅野市 & 18C. 中期 & & 48.5 & 40.0 & 37. & 5.1 & 1.6 & 0.4 & & & & & & $\mathrm{E}$ \\
\hline 津島杜 & 泰阜村 & 寛政 2 年 & 22 & 38.5 & 31.5 & 29.7 & 3.96 & 1.8 & 0.5 & & 4.0 & 5.0 & 佐今 & & A \\
\hline 本殿 & 堀金村 & 寛政 4 年 & 22 & 56.1 & 45.3 & 38.3 & 5.7 & 1.9 & 1.2 & & 4.2 & 7. 0 & 帴川豊八宅候 & 実則 & Ao \\
\hline$\pi$ & 三琪村 & 文化9 年 & 22 & 34.9 & 28.0 & 26.3 & 3.9 & 1.7 & 0.4 & 0.8 & $4 . \overline{3}$ & 5.4 & & 実測 & $\mathbf{E}$ \\
\hline 一王子神社本殿 & 八坂村 & 文化 6 年 & 20 & 22.9 & 18.5 & 19.7 & 2.64 & 1.7 & -0.5 & 0.8 & 3.8 & 2.8 & 内山久左衛門 & 奏湘 & $\mathrm{E}$ \\
\hline 八王子社本殿 & 梓川村 & 18c. 中期 & 18 & 36.0 & 29.5 & 31.2 & & & & 0.8 & 3.3 & 2.4 & & & - \\
\hline 崎弁財天社 & 梄川村 & 文政 6 年 & 22 & 16.8 & 13.6 & 12.1 & 1.82 & 1.8 & 0.8 & 0.8 & 4.2 & 6.2 & 原麻吉(上䑮) & 実測 & A \\
\hline 原神社本殿 & 飯山市 & 天明年間 & 22 & 48.4 & 39.4 & 35.0 & 4. 62 & 1.9 & 1.0 & & 4.1 & 6.1 & & 飯山 & A or D \\
\hline & 鬼無里村 & 宝歴12年 & 22 & 15. 6 & 12. & & 1.58 & 2.0 & 0.9 & & 4.4 & 6.3 & & & \\
\hline & 鬼無里村 & 文化 4 年 & 22 & 15.7 & 12.8 & 11.4 & 1.5 & 1.9 & 0.9 & & 4.1 & 6.0 & & & A or D \\
\hline 体殿 & 鬼無里村 & 章和年間 & 22 & 68.5 & 55.9 & 51.7 & 6.9 & 1.8 & 0.6 & & 4.1 & 5.4 & & & $\mathrm{E}$ \\
\hline & 須坂市 & 文政頃 & 22 & 30.8 & 25.2 & 23.9 & 3. & 1.7 & 0.4 & 0.8 & 4.0 & 4.9 & （立川流） & 実則 & A \\
\hline & 飯山市 & 肎糜年間 & 22 & 30.6 & 25.1 & 23.8 & 3.2 & 1.7 & 0.4 & & 4. 0 & 4. 9 & & 飯山 & A \\
\hline 神社本殿 & 伊荆市 & 文化12年 & 22 & 55.0 & 47.9 & 41.9 & 5.94 & 1.2 & 1.0 & 0.8 & 2.8 & 5.2 & 立行和四郎 & 1 㳄 & $\mathrm{E}$ \\
\hline 天 & 富士見町 & 文化 8 年 & 22 & 30.0 & 25.0 & 23. 1 & 2.97 & 1.7 & 0.6 & & 3.7 & 5.1 & 藤森広八 & & $\bar{E}$ \\
\hline
\end{tabular}

注 v）文献略号（図面の揭載されている出版物）

国宝：長野県文化財保護協会編「長野県の国宝・重要文化財建造物修理工事報告書」V,鄉土出版社, 1988

県史：「長野県史」美術建筑資料制 (2)建筑，(注7)

次：「長野県の近世社寺建筑」長野県教育委目会, 1982

2 次 : 「㔫野県の近世社寺建策」長野県教育委圆会, 1990

大河：大河直躬氏実湘 奏测：吉澤政已央测

飯山：【江户時代のお寺とお宮」饭山市教育委員会, 1992

塩尼：「塩尼市誌」第 4 巻, 塩尼市誌編箱委貝会, 1993 
大工が採用した柱間決定法が異なれば、全く異なった分 布を示すことがわかる。また、長野県と神奈川県の事例 では、江戸中期前半の分布が、ほかの時代と著しい違い を見せている点で共通している。江戸中期前半の分布か、 後の時代に緩やかな線でつながっていないので、江戸中 期前半は、地方の大工にとって柱間決定法を試行錯誤し た時代であったと推定される。

\section{6. 柱間決定法と大工}

表 $-5 \sim 6$ の時代別に、複数の建築を建てた大工が採 用した柱間决定法とタイプの概要は次のとおりである。

江戸前期までの大工では、八幡神社本殿・諏訪社本殿 (阿南町) および大山田神社相殿掂神天皇社本殿 (下条 村）を建てた吉村与照右衛門 ${ }^{20)}$ は、 $\mathrm{D}_{2}$ タイプをとって いる。八幡神社本殿と大山田神社相殿応神天皇社本殿は 寸法も柱間比率もほとんど同じであるが、諏訪社本殿の 場合は、寸法や向拝奥行の比率に相違がみられる。神明 社本殿・譀訪社本殿 (白馬村) および大宮諏訪神社本殿 （小谷村）は棟札から金原周防守が建てたことが知られ ている。彼の方法はD、タイプに属する。しかし、向拝奥 行の取り方は一定していない。子係とみられる金原周防 が建てた若一王子神社本殿(大町市、重要文化財)では、間 口に対する奥行の比率が上記のタイプに属していない。

江戸中期前半の大工ては、松本藩御大工中村四郎右衛 門が、小野神社本殿・八幡社本殿(塩尼市)および若宮八 幡社本殿(松本市、重要文化財) を建てている。若宮八幡 神社本殿では、大工頭が中村四郎右衛門、棟梁は田中治

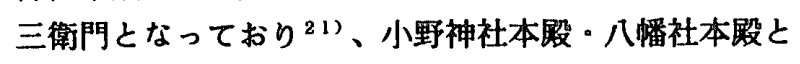
柱間寸法の此率も異なるので、田中治三衛門の柱間决定 法が取られていた可能性がある。この時代にAタイプを とる建築と大工についてみると、前述の中村四郎右衛門 は松本藩の大工であり、桐林八幡宮本殿(飯田市)を建て たのは三河の大工、子安社妙義社本殿(伊那市)は高遠藩 の大工到である。藩の大工や三河の大工には、早くか ら枝割による柱間決定法が䙎用されたものとみられる。

江戸中期後半の大工で、千鹿頭社本殿・手長神社本 殿・神戸八幡社本殿 (辰野町) を建てた丸山庄左衛門の 方法は、この分析では間口に対する奥行の割合 $(0.90)$ 以外に共通して属するタイプがない。彼はここで分析し た柱間决定法以外の方法 ${ }^{23)}$ 取っていたと推定される。 A夕イプをとる建築および大工をみると、前の時代にみ られた藩や城下町の大工として、林千鹿頭社本殿(松本 市)の中根弥七(松本城下)、若宮八幡宮本殿(上松町) ${ }^{24)}$ の田中儀兵衛（木曾代官山村氏の大工）があげられる。 このほかAタイプをとる建築には塩野神社本殿(上田市)、 八幡神社本殿(和田村)、諏訪社本殿(佐久市志賀)、八幡 神社天满宮本殿(同市新子田)、近津神社本殿(同市)があ
り、いずれも長野県で東信地方と呼ばれる地域の建筑で ある。東信地方にはこの時期にAタイプの柱間決定法を 㿟入していた大工が複数いたことがわかる。

江戸後期は、譀訪の立川和四郎や柴宮長左衛門㧍よび 彼らの門弟が活躍したことで知られている25)。表一 6 に見られるように、彼らの多くは間口に対する奥行の比 率を0.80にとっている。立川和四郎富昌の場合は、A夕 イプをとり、枝割で判断すると間口・奥行・向拝舆行を $22 \cdot 18 \cdot 17$ 枝としている。これは、『大匠蒦形』に記さ れた柱間決定法である。しかし、諏訪神社本殿（伊删市） はAタイプをとらす、間口に対する奥行の比率も他の建 築と異なっており、彼の初期の建築では柱間决定法を 1 つに固定していなかったものと推定される。

柴宮長左衛門矩重の場合は、AタイプあるいはDタイ プをとり、枝割で見た場合、22・18・17と22・18・16を 取っている。長左衛門の本家に伝わるく弥兵衛図〉は、 垂木数は20ではあるが、Dタイプに属する柱間決定法で、 向拝奥行は枝割や柱間から直接導かれていない。長左衛 門の建築で向遅柱間の决定法が一定していないことを考 えると、<弥兵衛図>の伝統が長左衛門の方法の中に生 きていた可能性がある。

\section{7. $ま こ ゅ$}

信濃の社寺建策の柱間寸法决定法をみると、江戸中期

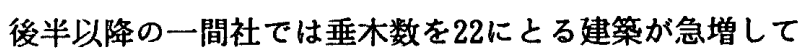
おり、また、間口に対する奥行の比率でも、比率0.80、 0. 90に近似しているものが過半数を占めている。これは、 江戸中期後半以降に『匠明』や『大匠嚾形』の方法に類 する方法が急速に普及したことに原因があると考えられ る。また、江戸中期前半は柱間決定法の武行錯誤の時期 であったこと、藩に属する大工や三河地方からの渡り大 工、東信地方の大工は比較的早い時期から枝割型を内在 する決定法を導入にしていたことが判明した。

しかし、1棟ごとにタイプをみていくと、ここで扱っ た技術書系の柱間決定法をそのまま導入している例は垂 木数の分布ほど顕著ではない。それぞれの大工が、こう した技術書の内容を意識しながら、独自の設計法を模索 していた様子が伺える。

謝辞

調查の仕方から報告書のまとめ方に至るまでに長年こ 指導下さっている千葉大学教授大河直躬博士に感謝致し ます。また、実测調査に快く参加して下さった星和彦氏、 渡刀道治氏に感謝致します。本稿の枝数・柱太さによる 平面分析を可能にする報告書を作成された関口欣也氏は じめスタッフ皆様に敬意を表します。 
注

1）内藤昌「大工技街書について」（建築史研究30，1961.10）、 近年のものでは、岡本真理子・渡辺勝彦・内藤昌「「思子見 記」の成立」(日本建筑学会計画系論文報告集第369号, 1986. 11，103 112頁）、河田克博・渡辺勝彦・内藤昌「江户建仁 寺流系本の成立」（日本建築学会計画系論文報告集第383号, 1988.1，121〜132頁）など一連の研労成果が報告されている。 また、重要文化財建造物と「匠明」を分析された石井邦信 「柱間・枝数・壱枝寸法」(日本建築学会大会学術講演梗概 集, 1984,2641 2642頁)、ほかがある。

2）都道府県別に実施されている「近世社寺建築緊急調查」の報 告書にまとめられている。また、地方の大工については、吉 岡泰英「福井藩大工の研究」（日本建築学会計画系論文報告 集第406号, 1989. 12,161～171面）、高橋恒夫「社寺普請にお ける気仙大工とその系譜について」（日本建築学会計画系論 文報告集第363号, 1986.5,125 135頁）ほかがある。

3）長野県内では、木割りを弲した建地割として、敦䘵 4 年の年 記がある「善光寺造営図」（重要文化財）、宝永 6 年に建て られた若一王子神社三重塔の建地割図が「長野県史」美術建 築資料䎤 (2)建筑（注 7) に紹介されている。刊行本以外で は、これらが建築計画を知る数少ない史料である。

4) 信州大学工学部社会開発工学科地域計画研觉室内に事務局の ある信州伝統的建造物保存技術研究会々員の複数の大工さん は、近世・近代の技術贵のとおりの向择勾配で建てると、長 野県の気候では、冬にすが漏れを起こしてしまうので、勾配 を強めに取るようにしているという。しかし、当初から本殿 が覆屋内部にあれば、本段の屋根は形式的なものであるから、 技術書通りの属根勾配も可能である。

5) 川上貢編「近世建筑の生重組耡と技術」（中央公論美術出版、 1984）では、京、大坂、汇戸周辺の近世大工の組織と技術が 解明されている。こうした研觉を念頭に直いて、中央から距 離のある信浱では、どうなのか考察したい。

6）本稿では、腢木入春日造も含めているので、正面の柱間を間 口、㑡面の柱間を奥行とよぶ。母屋の奥行きは単に奥行とよ ひ、向拝の奥行は向拝奥行とする。

7)「長野県史」美術建勧資料編 (2)建筑(曼野県史刊行会, 1990)

8）河田克博 - 麓和善 - 内藤昌「四天王寺流基幹本の書誌と構成」 （日本建築学会計画系論文報告集第412号, 1990, 109 117面)

9）本論では、太田博太郎 - 伊藤要太郎「匠明』（鹿島出版会， 1971）によった。「平作壱間社之図」として、正面柱間22枝、 㑡面柱間16枝、向拝の出15枝とある。また、「向妻作り壱間 社之图」では、正面柱間22枝、側面柱間20枝、向拝の出17枝 とある。柱の太さについては、「向妻作り壱間社の図」のな かに、柱太さ正面柱間の1/10、向拝柱太さは柱の8/10（但し 三間社のときは7/10）とある。

10）本論では、江戸科学古典漕書 35 「大匠手鑑・秘伝曹図解・大 工規矩尺集」（恒和出版，1982）によった。

「四尺五寸之宮」の項には、

一、柱のふとさ 間にて1寸2分かずへなり

一、はしかくしの柱ふとさ もや柱にて8分かずへ也

一、垂木の数八間内に18志中 そばのきに9志中はふ共に

一、つまの間八 おもての柱内法をとりてつまの柱中ずみ

ずみにあたる也

一、はしかくしの間八 妻の間の内法をとりて はしかくし

の柱中ずみにあつるなり

この場合、側面の柱間は支割りに拋っていない。間口を L

とすると、奥行は0.88L (15.8枝)、向择奥行は0.76 L (13.7

枝）となる。また、「一しゃ社之事」では、

一、柱のふよさ 間にて寸かずへなり

一、橋かくに、の杆ふとさ おや柱に8 分かずへなり

一、垂木の数八 間の内に 20 志ゅ

としている。

11) 本論では、江戸科学古典腾書23 「大匠難形・数寄屋工法集」 （恒和出版, 1979）によった。「一間社流作」では、
一、たる木のかず おもてに22枝、そばのきはふともに11枝、 つまの間に18枝、ごはいの間に17枝

一、柱の大サ 22枝の間にて寸かぞへ 丸はしらにて用 とおり、向择の柱の記述はないが、「一間社向作」（枝割り は「一間社流作」之同じ) の項に、「一、柱の大サ おもて の間にて寸かぞへ 丸柱、ごはい8角柱 ふとさ 8 分」とあ るので「一間社流作」でも同様と推定される。

12）この図の記載によれば、

たるき表間 20 枝/そば軒 11 枝破風共に/妻間 表間よ り柱 1 本狭く/縁広さ 6 枝小間半（中）/柱太さ 表間 にて寸かずへ/向拝柱 もや柱8分取り

向择奥行については記載がないが、木陼が柱の 6 分取り 5 級、 縁束が7分取りであるから、都合14枝となる。

なお、伊滕富夫氏の調查によれは、伊藤弥左衛門は権兵衛 光福を名乗り、正徳 4 年(1814)の生まれ、安永 9 年(1880)に 没している。建地割図に署名のある弥兵衛を名乗る人物は、 この時代の伊藤家にはいないが、図面が伝わっていることか らみれば、榴兵衛光福が弥兵衛を名乗った時期があったもの と推定される。光福の 3 男が本稿の $<6>$ で述べる柴宮長左 衛門矩重である。

13）掛子造は、中村達太郎「日本建築辞魚」（丸善, 1906）に紹介 されている柱間决定方法である。また、吉田高子「木割書に よる一間社流造柱間寸法決定法」（日本建築学会大会学術講 演梗概集, 1990, 881 882頁) に高木家文書「雑記」の掛子造 を分析している。柱太さの決定法は、この高木家文毒のもの （「柱向之間二而寸かそへ、向抨柱八柱

た。「日本建筑辞䋈」では掛子造は、

(i)奥行の外法寸法を正面柱間の内法寸法とする (2)奥行の内法寸法を向洋奥行の外法とする

とする。なお、高木家文書では、「間之取様八表之柱内法ヨ つまの間外法にして其内のりを取りて向洋柱外法に定る」と あり、間口の寸法を計算の始点としている。どちらも、析行 と梁行寸法の差は柱 2 本分となる。

14）「長野県宝武水別神社高良社社殿修理工事報告曹」（更埴市 教育委員会, 1994）、修理前の実测值は「長野県史」美術建 筑資料編 (2)建筑（注7）によった。なお、長野県では県指 定有形文化財を県宝と称している。

15）【重要文化財葛山落合神社本良修理工事報告書』（同修理委 貝会, 1985)

16）「重要文化剘大宮热田神社本殿若宮八幡宮本殿修理工事報告 書」（長野県教育委員会, 1953）

17）若宮八幡社本殿では、間口43寸晋 19 枝に割っているが、組物. の所では 1 枝を2.3寸とし、ほかは1枝が2. 25寸の割である と推定している（「重要文化財若宮八幡社本殷够理工事報告 書」同修理委貝会, 1982）。このような、微妙な割りは、解 体修理工事などの際の極めて詳細な調査によって判断される ことで、本稿では単糺に $43 \div 19=2.26$ 寸として、集計した。

18）前揭注15。

19）「神奈川䅫近世社寺建築調查報告贵」（神奈川県教育委員会, 1993）による。図面に垂木数の記述がないものでも、写真か ら垂木数が磪認できるものはこれを補った。

20）市村威人「吉村與椠右衛門一大山田・古城雨八幡社段を造営 したる大工頭一」（「信濃」III-4-11, 1952, 27〜28頁）

21）前揭住 7 。

22）「伊那市史」歴史編（伊那市, 1984）

23） 奥行 $=$ 間口 $\times 0.9$ 、向拝奥行 $=$ 奥行 $\times 0.9$ あるいは間口：奥 行: 向抨奥行=1:0.9:0.8の比率をとっている。

24）若宮八幡宮本殿は吹寄垂木としている。垂木間を点検した結 果、柱間を 22 枝に取ってから、途中の垂木を抜いて吹寄とし ていることが認められたので、表では22枝として計算した。

25）「長野県の近世社寺建築一第 2 次調查報告書一」（長野県教 育委員会, 1991）

(1994年 6 月 7 日原稿受理, 1995年 2 月 1 日採用決定) 